\title{
Nano-petrographic investigation of a mafic xenolith (maar de Beaunit, Massif Central, France)
}

\author{
FRANÇOIS FAURE ${ }^{1 *}$, GILLES TROLLIARD ${ }^{2}$, JEAN-MARC MONTEL ${ }^{1,3}$ and CHRISTIAN NICOLLET ${ }^{1}$ \\ ${ }^{1}$ UMR 6524 CNRS, OPGC - UBP, 5 rue Kessler, 63038 Clermont-Ferrand Cedex, France \\ * e-mail: f.faure@opgc.univ-bpclermont.fr \\ ${ }^{2}$ UMR 6638 CNRS, SPCTS, 123 avenue Albert Thomas, 87060 Limoges Cedex, France \\ ${ }^{3}$ UMR 5563 CNRS, MTG - UPS, 39 allées Jules Guesde, 31000 Toulouse, France
}

\begin{abstract}
The thermal history of a mafic xenolith from the Beaunit maar (Massif Central, France) is reconstructed at the basis of a transmission electron microscopy study. The protolith is a meta-microgabbro (opx1 , cpx-1, pl-1) sampled in the lower continental crust $\left(\mathrm{T}=870-970^{\circ} \mathrm{C}, \mathrm{P} \approx 0.7-0.8 \mathrm{GPa}\right)$. The incorporation in the basaltic magma produced five reactions around orthopyroxene: opx-1 $\Rightarrow \mathrm{cpx}-2 \Rightarrow \mathrm{cpx}-3$ (augite + high pigeonite) $\Rightarrow \mathrm{liq} \Rightarrow \mathrm{cpx}-4$. The final reaction is the transformation of residual cpx-3 (augite + high pigeonite) into cpx-5 (augite + low pigeonite). The calculation of the time required for each transformation yields a minimum residence time of the enclave in the host magma of 16 hours and a magma ascent velocity of $1.8 \mathrm{~km} \cdot \mathrm{h}^{-1}$. Exsolutions are produced by pressure decrease as the xenolith is brought up to the surface in the host basalt. Fractures observed in primary minerals are interpreted as a consequence of xenolith shocks against the wall of the magma conduit.
\end{abstract}

Key-words: xenolith, TEM, exsolution, pyroxene, ascent velocity.

\section{Introduction}

Xenoliths brought up to the surface by volcanoes are fascinating geological objects, because they constitute a natural sampling of deep rocks. They are a unique source of data on the chemical composition of the deep crust and upper mantle, give an opportunity to study the mineralogy of the deep parts of the lithosphere, and allow the reconstruction of a locally vertical section of the crust and the upper mantle. However, these "samples" are interesting only if they are not too much modified during the transport to the surface. Actually, because they have been incorporated in basalt, all xenoliths underwent pyrometamorphism, sometimes intense enough to induce partial melting. This is well known in acidic xenoliths, where melting textures have been described (Maury \& Bizouard, 1974; Harris \& Bell, 1982; Grapes, 1986; Graham et al., 1988), but melting textures in mafic xenolith have been only rarely reported.
Here we present a detailed petrographical study of "partially molten" mafic granulitic xenoliths from the Massif Central. Such xenoliths received little attention so far, because they were strongly affected by pyrometamorphism and melting. Combining optical microscopy, scanning electron microscopy (SEM) and transmission electron-microscope (TEM) investigations, the thermal history of this xenolith has been reconstructed. The opportunity to observe the sample through several orders of magnitude proved to be a powerful tool for characterising reaction mechanisms, and therefore the P-T history of the xenolith.

\section{Analytical techniques}

We used three complementary microscopes allowing observation from rock-scale to the crystal-lattice scale. The petrographical microscope and SEM allow one to identify mineral-mineral and mineral- 
melt reactions, TEM characterises phase transitions and very fine reaction textures. The SEM work was carried out with a Cambridge-Leica Stereoscan 360 instrument, equipped with an energy dispersive X-ray analyser at Université Blaise Pascal, Clermont-Ferrand. We used mainly the backscattered electron mode on polished thin sections, with $20 \mathrm{kV}$ accelerating voltage, $2 \mathrm{nA}$ probe current, $17 \mathrm{~mm}$ working distance. The microprobe analyses were performed with a Cameca Camebax at Université Blaise Pascal (Centre Régional de Mesure Physique), Clermont-Ferrand. Analytical conditions were $15 \mathrm{kV}$ accelerating voltage, $10 \mathrm{nA}$ beam current. Standards used for calibration are natural albite, orthoclase, olivine, wollastonite, synthetic $\mathrm{Fe}_{2} \mathrm{O}_{3}, \mathrm{Al}_{2} \mathrm{O}_{3}, \mathrm{MnTiO}_{3}$; ZAF correction procedures were applied. Analyses of glass were performed with a defocused beam in order to minimise alkali migration. For TEM work, the selected areas from thin section were mounted on $\mathrm{Cu}$ singlehole grids, thinned further by ion milling (Gatan Precision Ion Polishing System) and C-coated on both sides. The specimens were studied at Université de Limoges (Centre de Microscopie Electronique) in a $200 \mathrm{kV}$ TEM (JEOL 2010), equipped with an energy dispersive X-ray spectrometer (XEDS). Chemical analyses of thin foils were locally performed using convergent electron beam, the size of which ranges from 20 to $5 \mathrm{~nm}$. Quantitative informations were obtained by reference to internal standards, assuming that X-ray absorption and fluorescence can be ignored to a first approximation. For high-resolution electron microscopy (HREM) images, the determination of the local symmetry and periodicities of nanocrystals was performed using routines from the CRISP software (Hovmöller, 1992). In this case, selected areas of the negative photographs were digitized using a charge-coupled device video camera mounted above a light box.

\section{Sample description}

The studied xenoliths were sampled on the "Puy Gonnard" strombolian cone (Camus, 1975) located inside the "Maar de Beaunit" in the "Chaîne des Puys" (French Massif Central), dated at $43900 \pm$ 5100 a (Rosseel, 1996). This volcano contains a great variety of xenoliths: granites and gneisses from the upper crust, mafic and felsic granulites from the lower crust and peridotites from the upper mantle (Brousse \& Rudel, 1964; Leyreloup, 1973).
Table 1. Electron-microprobe analyses of the glass outside (basalt) and inside the xenolith.

\begin{tabular}{|c|c|c|c|c|c|c|}
\hline \multicolumn{7}{|c|}{ Basaltic glass } \\
\hline $\mathrm{SiO}_{2}$ & 49.18 & 49.80 & 49.33 & 49.07 & 48.35 & 48.54 \\
\hline $\mathrm{TiO}_{2}$ & 3.97 & 3.85 & 3.56 & 3.50 & 3.57 & 3.51 \\
\hline $\mathrm{Al}_{2} \mathrm{O}_{3}$ & 13.71 & 14.21 & 15.11 & 15.18 & 14.87 & 14.76 \\
\hline $\mathrm{Cr}_{2} \mathrm{O}_{3}$ & 0.00 & 0.14 & 0.00 & 0.03 & 0.00 & 0.03 \\
\hline $\mathrm{FeO}$ & 12.63 & 12.71 & 12.27 & 11.62 & 11.59 & 10.52 \\
\hline $\mathrm{MnO}$ & 0.24 & 0.21 & 0.23 & 0.24 & 0.22 & 0.23 \\
\hline $\mathrm{MgO}$ & 3.72 & 3.71 & 3.62 & 3.75 & 3.74 & 3.67 \\
\hline $\mathrm{CaO}$ & 7.99 & 7.71 & 8.31 & 8.15 & 7.78 & 7.45 \\
\hline $\mathrm{Na}_{2} \mathrm{O}$ & 3.73 & 3.66 & 2.98 & 3.70 & 3.97 & 5.04 \\
\hline $\mathrm{K}_{2} \mathrm{O}$ & 2.84 & 2.67 & 2.81 & 3.34 & 3.54 & 3.47 \\
\hline $\mathrm{ZnO}$ & 0.00 & 0.00 & 0.07 & 0.16 & 0.05 & 0.01 \\
\hline Sum & 98.01 & 98.65 & 98.29 & 98.74 & 97.69 & 97.24 \\
\hline \multicolumn{7}{|c|}{ Glass inside the xenolith } \\
\hline $\mathrm{SiO}_{2}$ & 49.72 & 50.15 & 50.61 & 47.69 & 48.18 & 48.81 \\
\hline $\mathrm{TiO}_{2}$ & 3.57 & 3.67 & 3.28 & 3.38 & 3.35 & 3.29 \\
\hline $\mathrm{Al}_{2} \mathrm{O}_{3}$ & 14.21 & 14.09 & 14.56 & 14.32 & 14.76 & 14.6 \\
\hline $\mathrm{Cr}_{2} \mathrm{O}_{3}$ & 0.00 & 0.00 & 0.06 & 0.01 & 0.04 & 0.02 \\
\hline $\mathrm{FeO}$ & 12.50 & 13.15 & 12.77 & 11.83 & 11.64 & 11.57 \\
\hline $\mathrm{MnO}$ & 0.09 & 0.00 & 0.23 & 0.19 & 0.10 & 0.26 \\
\hline $\mathrm{MgO}$ & 3.38 & 3.74 & 3.41 & 3.84 & 3.80 & 3.77 \\
\hline $\mathrm{CaO}$ & 7.96 & 7.72 & 7.75 & 8.38 & 7.41 & 7.86 \\
\hline $\mathrm{Na}_{2} \mathrm{O}$ & 3.54 & 3.01 & 3.29 & 3.57 & 4.07 & 3.89 \\
\hline $\mathrm{K}_{2} \mathrm{O}$ & 2.61 & 2.88 & 3.06 & 3.26 & 3.81 & 3.84 \\
\hline $\mathrm{ZnO}$ & 0.16 & 0.00 & 0.16 & 0.12 & 0.00 & 0.00 \\
\hline Sum & 97.73 & 98.40 & 99.18 & 96.58 & 97.17 & 97.92 \\
\hline
\end{tabular}

The studied mafic xenolith is several cubic centimetres in size, surrounded by a mm-thick layer of vesicular and highly scoriated basalt (Rosseel, 1996). The basalt is essentially made of clinopyroxene and olivine phenocrysts, plagioclase microlites and tiny oxide crystals, embedded in brown glass. The xenolith itself is fine-grained, with white feldspars and brown pyroxenes. It contains abundant brown interstitial pockets of glass, which isolate small pyroxene aggregates. Inside the xenolith, the glass is lighter than in the surrounding basalt, but electron-microprobe investigations did not reveal significant differences in chemical composition (Table 1). Plagioclase microlites $\left(\mathrm{An}_{65}\right)$ in the glass are observed both inside glass pockets within the xenolith and in the host lava. The glass inside the xenolith also contains abundant olivine $\left(\mathrm{Fo}_{65}\right)$ and opaque minerals.

The petrological study of the xenolith itself allows one to distinguish a primary mineral association including plagioclase (pl-1), clinopyroxene (cpx-1) and orthopyroxene (opx-1) (Table 2), which is a typical assemblage for lower-crustal mafic xenoliths in this area. 
Table 2. Representative electron-microprobe analyses of minerals in the mafic xenolith (opx, orthopyroxene; cpx, clinopyroxene; Pl, plagioclase).

\begin{tabular}{|c|c|c|c|c|c|c|c|c|c|c|c|c|c|}
\hline $\begin{array}{l}\text { Compo- } \\
\text { sition } \\
\text { (in wt \%) }\end{array}$ & Cpx-1 & Cpx-2 & Cpx-1 & Cpx-2 & $\begin{array}{r}\text { Opx-1 } \\
\text { core }\end{array}$ & $\begin{array}{r}\text { Opx-1 } \\
\text { rim }\end{array}$ & $\begin{array}{r}\text { Opx-1 } \\
\text { core }\end{array}$ & $\begin{array}{r}\text { Opx-1 } \\
\text { rim }\end{array}$ & $\begin{array}{r}\text { (in } \\
\text { wt \%) }\end{array}$ & Pl-1 & Pl-1 & Pl-1 & $\mathrm{Pl}-1$ \\
\hline $\mathrm{SiO}_{2}$ & 50.74 & 50.53 & 50.51 & 49.43 & 51.77 & 51.64 & 51.04 & 51.31 & $\mathrm{SiO}_{2}$ & 55.92 & 51.77 & 53.29 & 49.1 \\
\hline $\mathrm{TiO}_{2}$ & 0.81 & 1.25 & 0.84 & 1.83 & 0.10 & 0.24 & 0.15 & 0.23 & $\mathrm{TiO}_{2}$ & 0.09 & 0.23 & 0.00 & 0.09 \\
\hline $\mathrm{Al}_{2} \mathrm{O}_{3}$ & 3.46 & 3.05 & 3.23 & 3.63 & 1.46 & 1.33 & 1.36 & 1.45 & $\mathrm{Al}_{2} \mathrm{O}_{3}$ & 27.11 & 29.88 & 29.41 & 31.70 \\
\hline $\mathrm{Cr}_{2} \mathrm{O}_{3}$ & 0.07 & 0.15 & 0.06 & 0.05 & 0.13 & 0.00 & 0.02 & 0.01 & $\mathrm{Cr}_{2} \mathrm{O}_{3}$ & 0.00 & 0.00 & 0.06 & 0.12 \\
\hline $\mathrm{FeO}$ & 15.58 & 10.92 & 14.30 & 8.11 & 26.35 & 25.76 & 25.82 & 25.55 & $\mathrm{FeO}$ & 0.41 & 0.68 & 0.47 & 0.53 \\
\hline $\mathrm{MnO}$ & 1.13 & 0.34 & 0.38 & 0.25 & 0.67 & 0.55 & 0.68 & 1.06 & $\mathrm{MnO}$ & 0.03 & 0.04 & 0.01 & 0.04 \\
\hline $\mathrm{MgO}$ & 13.65 & 14.43 & 12.96 & 13.93 & 19.57 & 18.64 & 18.82 & 18.91 & $\mathrm{MgO}$ & 0.06 & 0.10 & 0.11 & 0.09 \\
\hline $\mathrm{CaO}$ & 15.53 & 19.58 & 17.20 & 21.41 & 0.66 & 1.42 & 0.80 & 0.86 & $\mathrm{CaO}$ & 10.31 & 12.98 & 12.14 & 15.40 \\
\hline $\mathrm{Na}_{2} \mathrm{O}$ & 32 & 0.3 & 0. & 0.50 & 0.03 & 0.02 & 0.00 & 0.03 & $\mathrm{Na}_{2} \mathrm{O}$ & 4.72 & 3.64 & 3.76 & 2.56 \\
\hline $\mathrm{K}_{2} \mathrm{O}$ & 0.01 & 0.02 & 0.00 & 0.00 & 0.00 & 0.02 & 0.00 & 0.03 & $\mathrm{~K}_{2} \mathrm{O}$ & 1.38 & 0.32 & 0.68 & 0.29 \\
\hline Sum & 101.30 & 100.66 & 99.76 & 99.14 & 100.74 & 99.62 & 98.69 & 99.44 & Sum & 100.03 & 99.64 & 99.93 & 99.92 \\
\hline \multicolumn{9}{|c|}{ umber of cations on the basis of 6 oxygens } & \multicolumn{5}{|c|}{ Number of ions on the basis of 32 oxygen } \\
\hline $\mathrm{Si}$ & 1.898 & 1.885 & 1.913 & 1.861 & 1.954 & 1.968 & 1.965 & 1.959 & $\mathrm{Si}$ & 10.116 & 9.456 & 9.672 & 9.014 \\
\hline $\mathrm{Al}^{\mathrm{IV}}$ & 0.102 & 0.115 & 0.087 & 0.139 & 0.046 & 0.032 & 0.035 & 0.041 & $\mathrm{Ti}$ & 0.012 & 0.031 & 0.000 & 0.013 \\
\hline $\mathrm{Al}^{\mathrm{VI}}$ & 0.050 & 0.018 & 0.057 & 0.022 & 0.018 & 0.027 & 0.026 & 0.024 & $\mathrm{Al}$ & 5.780 & 6.432 & 6.291 & 6.859 \\
\hline $\mathrm{Ti}$ & 0.022 & 0.035 & 0.024 & 0.051 & 0.002 & 0.006 & 0.004 & 0.006 & $\mathrm{Fe}$ & 0.062 & 0.103 & 0.071 & 0.081 \\
\hline $\mathrm{Fe}^{3+}$ & 0.023 & 0.012 & 0.009 & 0.015 & 0.013 & 0.016 & 0.011 & 0.020 & $\mathrm{Mg}$ & 0.016 & 0.027 & 0.029 & 0.024 \\
\hline $\mathrm{Cr}$ & 0.002 & 0.004 & 0.001 & 0.001 & 0.004 & 0.000 & 0.000 & 0.000 & $\mathrm{Ca}$ & 1.999 & 2.541 & 2.361 & 3.029 \\
\hline $\mathrm{Fe}^{2+}$ & 0.464 & 0.328 & 0.444 & 0.240 & 0.818 & 0.805 & 0.820 & 0.796 & $\mathrm{Na}$ & 1.654 & 1.290 & 1.322 & 0.909 \\
\hline $\mathrm{Mn}$ & 0.036 & 0.010 & 0.012 & 0.008 & 0.021 & 0.017 & 0.022 & 0.034 & $\mathrm{Mn}$ & 0.005 & 0.005 & 0.001 & 0.005 \\
\hline $\mathrm{Mg}$ & 0.761 & 0.802 & 0.731 & 0.782 & 1.101 & 1.059 & 1.079 & 1.076 & $\mathrm{~K}$ & 0.317 & 0.074 & 0.156 & 0.067 \\
\hline $\mathrm{Ca}$ & 0.622 & 0.782 & 0.698 & 0.864 & 0.026 & 0.058 & 0.033 & 0.035 & $\mathrm{Cr}$ & 0.000 & 0.000 & 0.008 & 0.017 \\
\hline $\mathrm{Na}$ & 0.023 & 0.028 & 0.020 & 0.036 & 0.001 & 0.001 & 0.000 & 0.002 & Sum & 19.965 & 19.976 & 19.914 & 20.021 \\
\hline K & 0.000 & 0.001 & 0.000 & 0.000 & 0.000 & 0.000 & 0.000 & 0.001 & & & & & \\
\hline \multirow[t]{2}{*}{ Sum } & 4.012 & 4.024 & 3.999 & 4.023 & 4.008 & 3.995 & 3.998 & 4.002 & $\mathrm{Ab}$ & 0.416 & 0.330 & 0.344 & 0.227 \\
\hline & & & & & & & & & Or & 0.080 & 0.018 & 0.040 & 0.016 \\
\hline Wo & 0.326 & 0.404 & 0.368 & 0.452 & 0.013 & 0.029 & 0.016 & 0.018 & An & 0.503 & 0.650 & 0.614 & 0.756 \\
\hline En & 0.399 & 0.414 & 0.386 & 0.409 & 0.555 & 0.541 & 0.549 & 0.548 & & & & & \\
\hline Fs & 0.274 & 0.181 & 0.245 & 0.138 & 0.430 & 0.428 & 0.434 & 0.433 & & & & & \\
\hline
\end{tabular}

- The plagioclase $\left(\mathrm{An}_{54-76}\right)$ crystals, 3-4 $\mathrm{mm}$ in size, are generally broken or display wrapped twins and undulose extinction. The glass is located both at the plagioclase periphery and inside the mineral. Plagioclase-glass contacts show sawtooth texture.

- Clinopyroxene (cpx-1) displays either a homogeneous texture or a sieve texture. As previously noted, crystals are surrounded by a glassy phase. Crystals are fractured and even the fresh ones are broken into small fragments at crystal rim. Along the clinopyroxene-glass contact, newly formed clinopyroxene crystals with a different coloration are also observed (cpx-2 analysis in Table 2). These crystals are more $\mathrm{Al}$ and Ti-rich than cpx-1. The orthopyroxene, also surrounded by an abundant glassy phase (Fig. 1), exhibits spectacular reaction textures.

a) Inside the xenolith the orthopyroxene crystals display a single corona of clinopyroxene, which may be very thick $(100 \mu \mathrm{m})$. b) In external parts of the xenolith, the orthopyroxene crystals are totally rimmed by a double corona. The inner part of the corona consists in clinopyroxene which, in turn, is rimmed by an olivine layer (Fig. 1).

\section{Reaction textures}

A detailed study (TEM) of the structure in the outer part of the xenolith has been carried out in order to clarify the textural relationships among the minerals.

\section{Orthopyroxene breakdown reactions}

Inner rim (cpx-2)

In the inner part of the reaction corona, micrometre sized cpx-2 crystals show epitactic relationships 

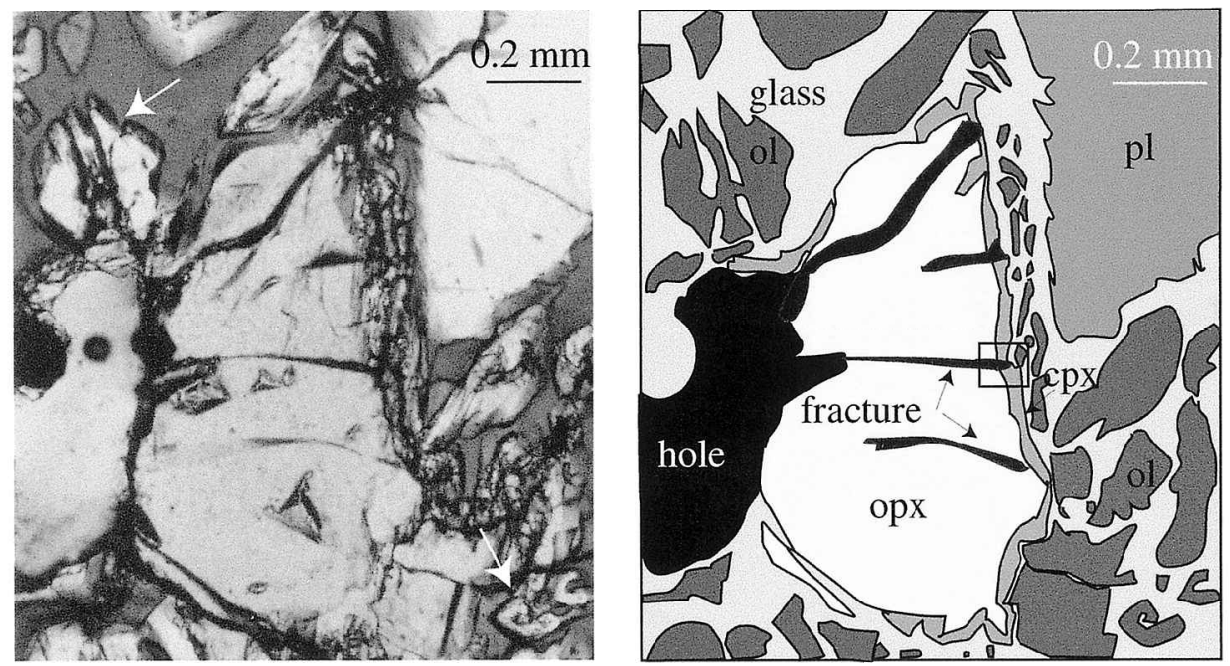

Fig. 1. Photomicrograph and sketch drawing of the orthopyroxene (opx) reaction site located at the edge of the xenolith. The opx is entirely surrounded by a corona of clinopyroxene (cpx). The cpx is rimmed by a discontinuous layer of olivine. Olivine sometimes displays hopper texture (see arrow). The box locates the area displayed on Fig. 2.

with the opx-1, even when cpx is apparently separated from opx by glass (Fig. 2a-b-c). The contact between the two minerals is not regular and relictual opx are sometimes trapped in the core of cpx grains (Fig. 2a). These observations account for a topotactic growth of cpx-2 on opx-1. Near the cpx-2 - opx interface, a $P$-mode, Fe-Mg-rich clinopyroxene is often present. This phase is characterised by a $9 \AA$ periodicity of the (100) planes (Fig. 2d). According to Kohlsed \& Vander Sande (1976), this characterises low pigeonite. A fracture, which crosscuts the observed area (Fig. 2a), contains clay minerals, assumed to result from the alteration of the glass. Fractures are thus developed before the glass solidification.

\section{Outer rim (olivine)}

Figure 3 shows that the olivine $\left(\mathrm{Fo}_{65}\right)$ displays hopper crystal morphologies (Lofgren \& Donaldson, 1975; Donaldson, 1976, 1977), quench needles (Laporte \& Watson, 1995) and many vitreous inclusions (Dixon et al., 1986). All these observations suggest rapid growth during quench. HREM images obtained along the [001] zone axis orientation of the olivine show that the olivine - glass contact is sharp (Fig. 4) with no evidence of alteration (iddingsitisation). However, along the interface we can note the presence of small "buds", 5 to $10 \mathrm{~nm}$ in size (Fig. 4b). Owing to their small thickness, these features are overlapped by the glass, which prevented us from obtaining good TEM images or EDS analyses. We digitized the HREM micrograph and calculated power spectra, which represents $[512 \times 512]$ Fourier transforms of selected regions (Fig. 4c-d). This reveals a periodicity of about $10 \AA$ suggesting that these "buds" are laihunite (distorted olivine structure with $\mathrm{Fe}^{3+}$ charge balanced by vacancies), a phase already reported to occur in forsterite-rich olivine by Banfield et al. (1990). This phase is monoclinic with $\alpha=91^{\circ}$ (Tamada et al., 1983). It is know to increase the resistance of olivine to weathering (Banfield $e t$ al., 1990). The laihunite lattice parameters are close to those of olivine: $a_{\text {laihunite }}=4.81 \AA, b_{\text {laihunite }}=10.43-$ $10.44 \AA$ and $c_{\text {laihunite }}=5.93-5.99 \AA$ (Kondoh et al., 1985). Therefore, we suggest that these buds could be laihunite which grows in epitaxy on the olivine. The crystallographic relationship between the two minerals can thus be established as follows: $[001]_{\text {lai- }}$ hunite $/ /[001]_{\text {olivine }}$ and (010) laihunite $/ /(100)_{\text {olivine. The }}$ rotation of $90^{\circ}$, around the $c$ axis, of the laihunite lattice with respect to olivine is likely to result from the limitation of the elastic strain at the interface between these two minerals. Indeed, $\boldsymbol{\beta}_{\text {laihunite }}=\boldsymbol{\alpha}_{\text {olivine }}=$ $90^{\circ}$ while $\alpha_{\text {laihunite }}=91^{\circ}$.

\section{Other reactions}

Several other types of reaction, all concerning pyroxenes, were revealed by TEM observations. Fig- 

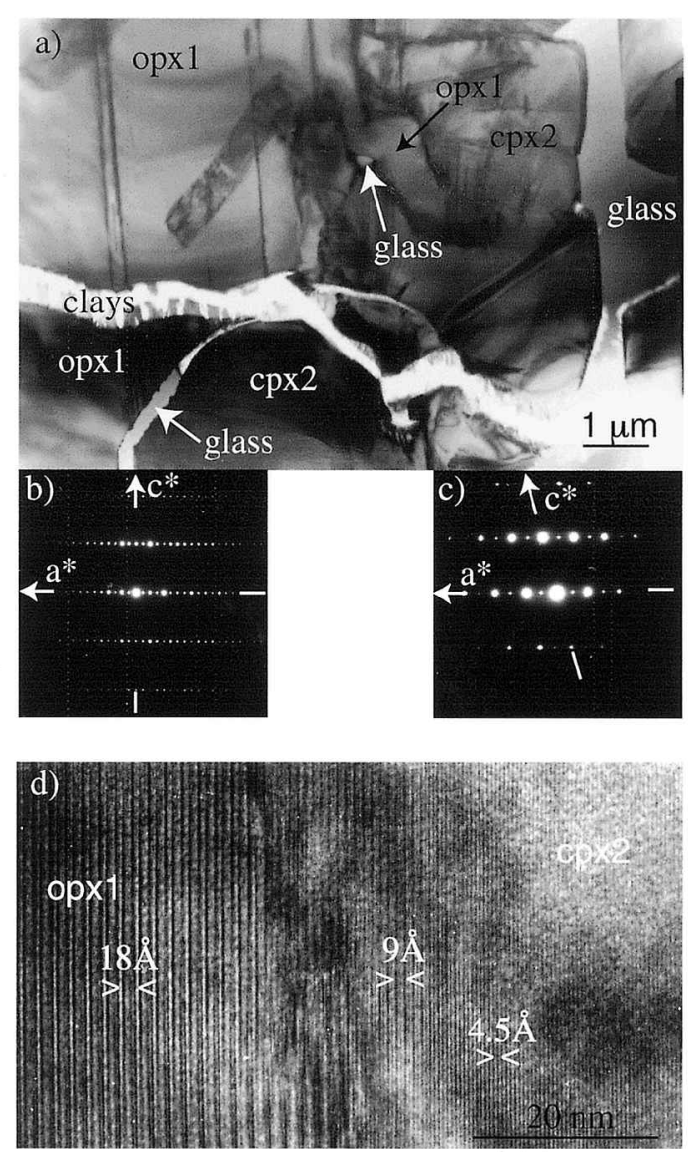

Fig. 2. Conventional TEM imaging showing the opx-1 reaction site.

a) Overview, bright field image showing the location of an opx pocket trapped in the cpx-2 corona.

b-c) [010] zone axis selected area diffraction patterns obtained on opx-1 and cpx-2, respectively.

d) High-resolution image of the opx-1/cpx-2 contact obtained under the [010] orientation. The periodicity of the (100) fringes is indicated. Between the opx-1 (18 A periodicity) and the cpx-2 (4.5 ̊ periodicity) a thick layer of pigeonite (9 ̊ periodicity) is commomly observed.

ure 5 represents an interface between a crystal of clinopyroxene (cpx-2) and a glassy phase. The presence of internal glass pockets can be attributed either to a section effect or to a local melting texture (see below).

- In the outer part of this crystal, an exsolution process takes place, giving rise to (001) and (100) lamellae (Fig. 5a-b), $50 \mathrm{~nm}$ thick. Selected-area electron-diffraction (SAED) pattern (Fig. 5e) indicates that they are $P 2_{1} / c$ pigeonite lamellae exsol-

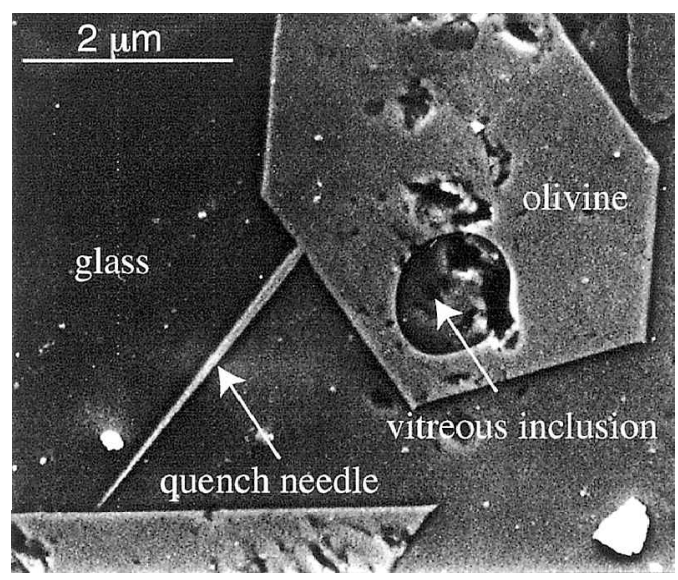

Fig. 3. SEM image showing olivine in glass near opx-1. Olivine displays quench textures: quench needle and vitreous inclusions.

ved within a $C 2 / c$ matrix (Bailey et al., 1970; Copley et al., 1974; Fuess et al., 1986). This is confirmed by dark-field imaging (using $(h+k)$ odd reflections of $P 2_{1} / c$ ) and XEDS analysis. This exsolution results in the formation of cpx-3 (augite + pigeonite).

- In the core of the same clinopyroxene (cpx-2), a tweed texture is apparent (Fig. 5a-c), which is characterised in the SAED pattern by stretching of the diffraction spots (Fig. 5d) parallel to $\mathbf{a}^{*}$ and $\mathbf{c}^{*}$ (Nord et al., 1976; Feuer et al., 1989). Bulk analyses performed with a defocused electron beam reveal that the composition of the clinopyroxene is very similar in the core and near the rim of the mineral. The difference observed between the exsolution patterns (lamellae or tweed pattern) is thus more likely due to kinetic reasons than to the variation of composition of the parent clinopyroxene (cpx-2).

- Both orthopyroxene/glass and clinopyroxene (cpx-2; cpx-3)/glass contacts frequently show a "stair-like" geometry (Fig. 6a-c). In bright-field images, these interfaces display a high diffraction contrast (Fig. 6b-c) which suggests the presence of a crystallised phase located along the (opx/glass) and (cpx/glass) interface. High-resolution images obtained along the [010] zone axis of opx (Fig. 6d) as well as nano-diffraction patterns obtained on these crystals (Fig. 6e) reveal that they consist of a $C 2 / c$ clinopyroxene (cpx-4). This clinopyroxene is significantly enriched in magnesium compared to the secondary cpx phase (cpx-2). Such nano-sized crystals of cpx grew in epitaxy either on the opx 


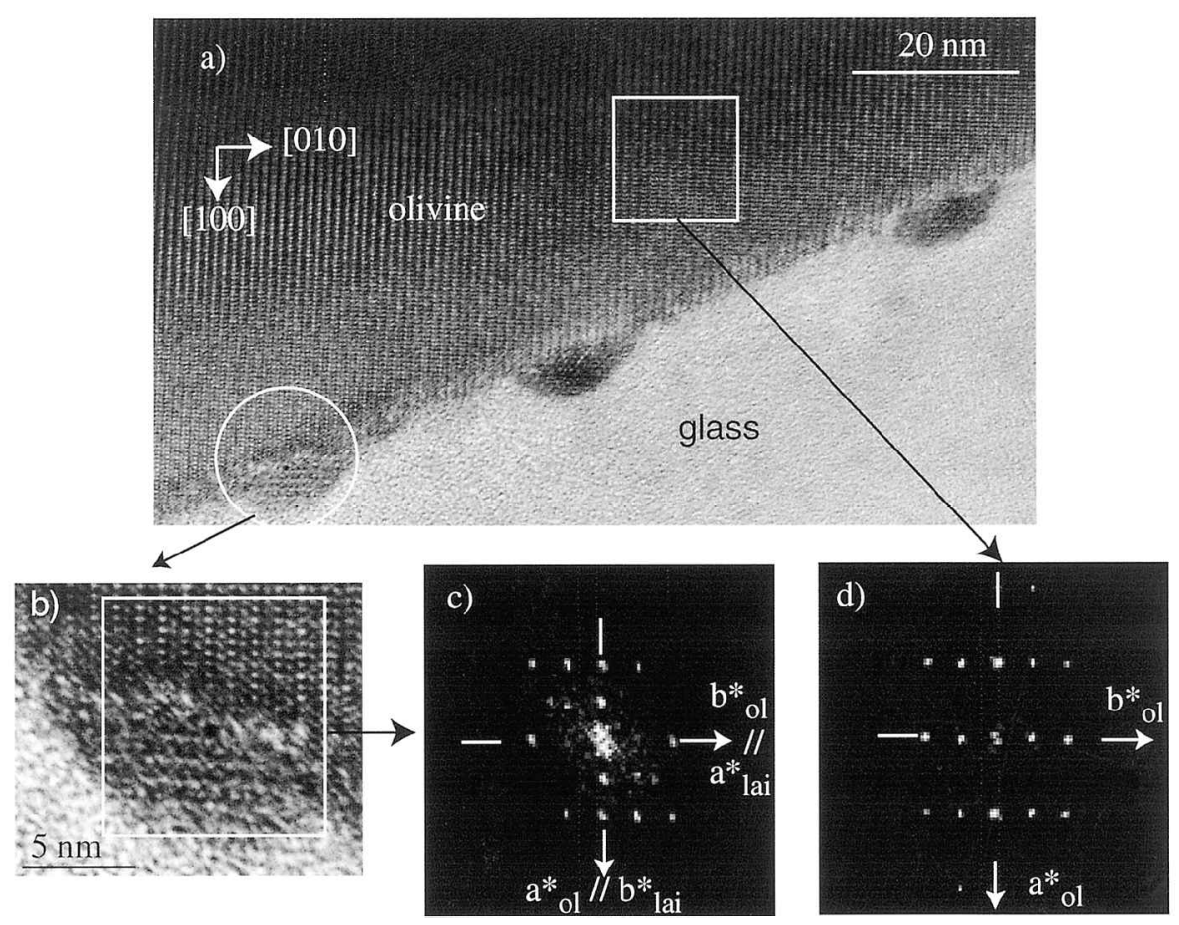

Fig. 4. TEM observation of the olivine-glasscontact.

a) Bright-field image showing the presence of small buds at the glass-olivinecontact.

b) Enlargement of the circled area in (a).

c) [001] zone axis power spectrum of both olivine and laihunite obtained after a [512 $\times 512]$ Fourier transform of the area selectedin (b).

d) [001] zone axis power spectrum obtained after a [512 $\times 512]$ Fourier transform of the square area selected in (a).

(opx-1) or on the cpx (cpx-2, cpx-3) lattice. They typically crosscut the exsolution lamellae previously developed in the cpx-2.

In addition, opaque minerals (Fig. 6d-f) are sometimes observed, epitactically oriented on these tiny cpx-4 crystals. Nano-diffraction experiments as well as chemical analysis performed on these crystals indicate that they are ilmenite. Indeed, the [010] zone axis diffraction pattern provided in Fig. $6 \mathrm{f}$ allows the distinction between hematite $(R \overline{3} c$ space group) and ilmenite ( $R \overline{3}$ space group).

\section{Interpretation}

\section{Origin of the glass}

Two main hypotheses can be proposed to explain the presence of an abundant glassy phase in the xenolith: partial melting of the xenolith itself, or infiltration of the surrounding basaltic liquid. The chemical data, as well as the presence of plagioclase microlites, suggest that a large proportion of the glass within the xenolith results from the infiltration of the host basalt. Such a situation has been previously described by O'Reilly et al. (1989). However, the observed texture indicates that the primary assemblage melted too, as a response to pyrometamorphism: (1) plagioclase displays serrated contacts with the glass, a feature that is commonly interpreted as a melting texture (Tsuchiyama \& Takahashi, 1983; Dixon et al., 1986; Chen \& Arculus, 1995); (2) for clinopyroxene, the observations suggesting melting are the sieve texture (Tsuchiyama, 1986) and the $\mathrm{TiO}_{2}$-enrichment toward the rim (Lee et al., 1993); (3) the reaction texture around opx-1 (giving cpx-2 and olivine) can also be interpreted as a melting reaction according to Berger \& Forette (1975) or Warner \& Wasilewski (1995). Therefore we can conclude that, although dominantly formed by the infiltration of the host lava, the glass 


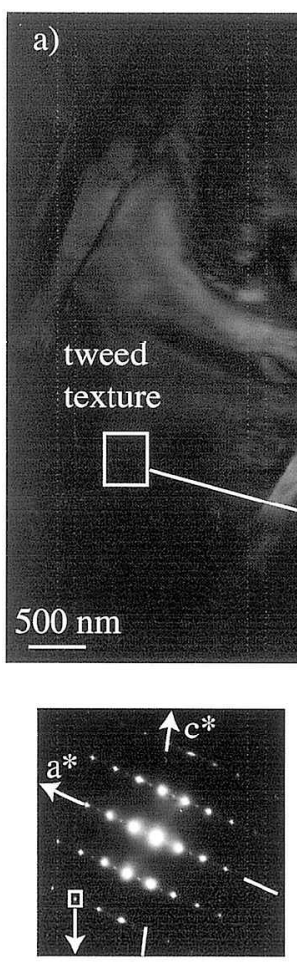

d)

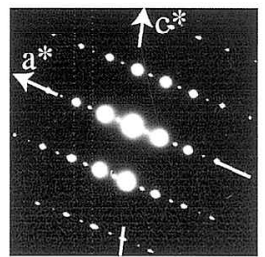

e)
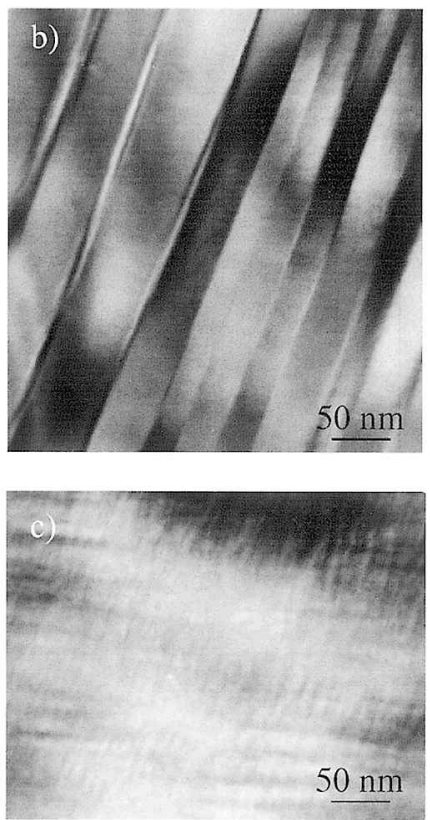

Fig. 5. TEM observations of the exsolution in cpx-2.

a) General overview showing the phase distribution.

b) Bright-field imaging of the thick exsolution lamellae situated in the external part of the rim of cpx-2.

c) Bright-field imaging of the tweed texture.

d) SAED pattern of the core of cpx-2 obtained along the [010] zone axis.

e) SAED pattern of pigeonite obtained along the [010] zone axis.

in the xenolith is probably also formed by partial melting of the xenolith itself. Similarly, Wysoczanski et al. (1995) interpreted the glass within the symplectites surrounding orthopyroxene as the product of interaction between xenolith and the host melt.

\section{Thermobarometric history}

A thermal history for this xenolith can be inferred from the petrographic observations (optical microscopy, SEM, TEM).

\section{Initial paragenesis}

The protolith is a mafic granulite initially containing opx-1, cpx-1 and pl-1. An estimate of the chemical composition of the rock has been obtained from the modal proportion and the chemical compositions of minerals. For this composition, the absence of garnet, according to Green \& Ringwood (1967) and Green (1967) indicates a maximum pressure of 0.7$0.8 \mathrm{GPa}$. Two-pyroxene-thermometry using pyroxene cores with the calibration of Berman (1991) yielded temperatures ranging from 870 to $970^{\circ} \mathrm{C}$. These results are consistent with those obtained by Dostal et al. (1980) and Downes et al. (1990) and correspond to lower-crustal granulite facies.

\section{Opx-1 $\Rightarrow$ cpx-2 reaction}

The topotactic orthoenstatite (opx-1) $\Rightarrow$ clinoenstatite (cpx-2) reaction has been experimentally studied by high-temperature transmission electron micros- 

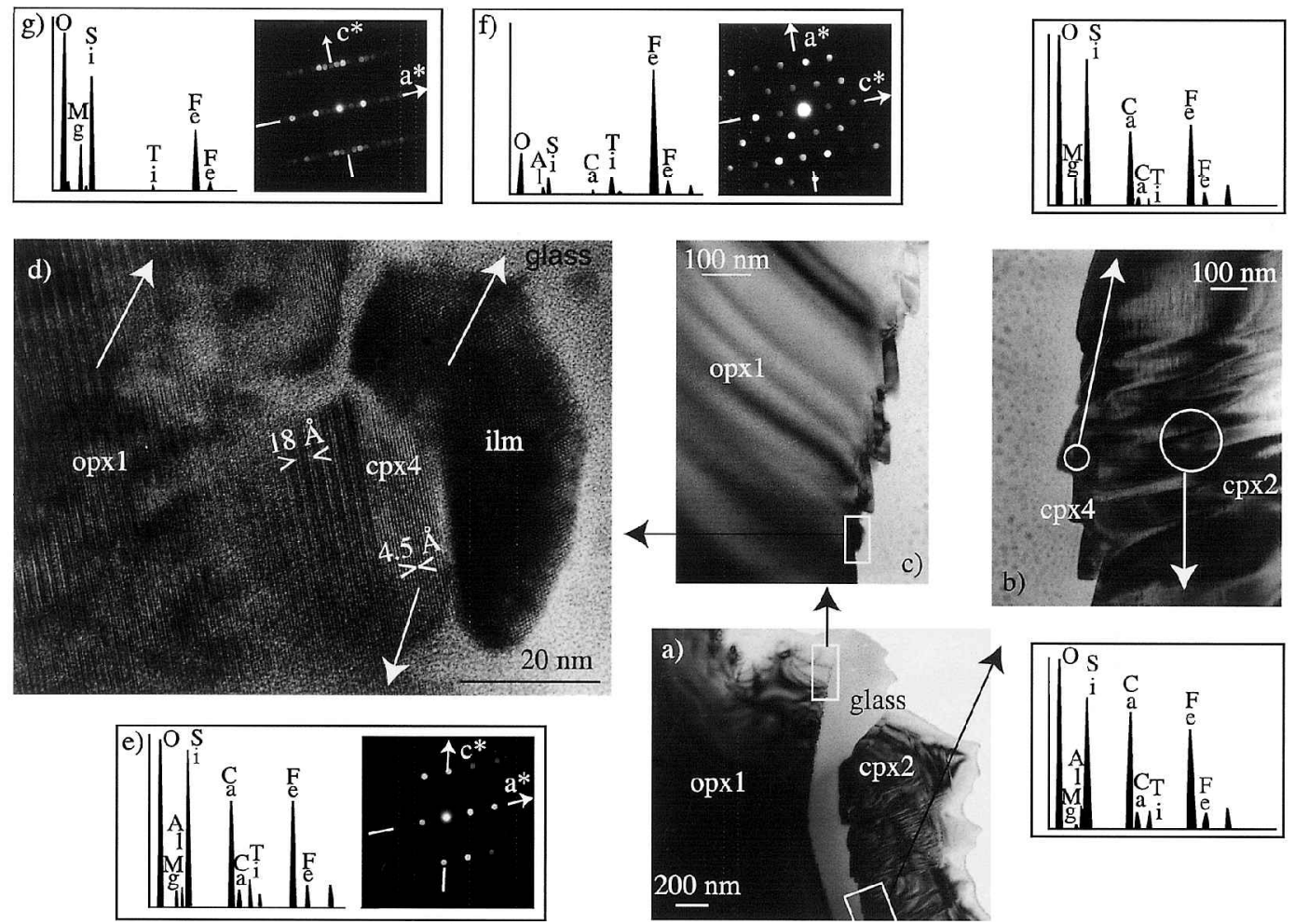

Fig. 6. TEM observation showing the crystallisation of $\mathrm{cpx}-4$.

a) Overview of an opx-1/cpx-2 contact. The two minerals are separated by an abundant layer of glass.

b) Enlargement of the cpx-2/glass contact showing a stair-like interface. Cpx-4 developed between these two phases. EDS spectra of the bulk cpx-2 and cpx-4 are reported (see arrows).

c) Enlargement of the opx-1/glass contact showing also a stair-like interface. Crystals of cpx-4 of hundred nm in size are present at the opx-1 contact.

d) HREM image obtained with a [010] zone axis of the opx-1/cpx-4 contact.

e) SAED of cpx-4 and the relevant EDS analysis.

f) SAED of the ilmenitecrystal with the corresponding EDS spectrum.

g) SAED of opx-1 with the corresponding EDS spectrum.

copy (HTTEM) (Shimobayashi \& Kitamura, 1993). It was shown that this reaction proceeds only for temperatures higher than $1200^{\circ} \mathrm{C}$. Because of this high temperature of reaction, we think that the transformation (opx-1 to cpx-2) corresponds to the incorporation of the xenolith into the host magma. This hypothesis is supported by the increase of $\mathrm{Al}$ and $\mathrm{Ti}$ in clinopyroxene-2 (Table 2) which marks a high-temperature origin (Usselman et al., 1975). The calcium necessary to form the clinopyroxene probably comes from the host basalt or from plagioclase melting.

\section{Reactions inside cpx-2}

Other reactions (exsolution and spinodal decompositions) occurred later, since they are observed only in cpx-2. Exsolutions are usually interpreted as resulting from a temperature decrease (Robinson, 1980; Dixon et al., 1986). It is however unlikely for this xenolith, because the initial magma temperature is slightly above $1200^{\circ} \mathrm{C}$ (see above) whereas eruption temperature calculated from the quenched olivinemelt equilibrium (Jurewicz \& Watson, 1988) is around $1125^{\circ} \mathrm{C}$, only $75^{\circ} \mathrm{C}$ below the initial temperature. On the other hand, the pressure variation may have been as high as $0.7-0.8 \mathrm{GPa}$ (pressure difference between surface and lower crust), a drop of 
pressure significant enough to produce exsolutions when xenoliths are brought up to the surface in the host basalt (see reaction 3 below).

The overall exsolution pattern is complex, so thick exsolution lamellae and spinodal decomposition textures have to be considered separately. On the one hand, the exsolution that leads to the formation of thick lamellae $(50 \mathrm{~nm})$ of $C 2 / c$ high pigeonite within the $C 2 / c$ augite is inconsistent with rapid cooling. The formation of these thick lamellae is thus supposed to be initiated in the crustal basement, and their thickness will be considered in the following discussion as a measure of the ascent time of the xenolith. On the other hand, the spinodal decomposition is a more rapid phenomenon (Champness \& Lorimer, 1976) and may result from cooling of the xenolith during the eruption.

\section{Other reactions}

Several other reactions can be incorporated in the xenolith history. The fourth generation of clinopyroxene (cpx-4) post-dates the formation of cpx-3 (augite + high pigeonite) and opx-1, because it grows epitactically on both. The opaque minerals (ilmenite) epitactically grew on cpx-4 (Fig. 6d-f) and are therefore more recent.

The incipient formation of olivine crystals could not be ascertained precisely, as olivine textures (hopper, quench needle) only depend on undercooling conditions. Olivine crystallisation could result from the liquid produced by melting of cpx-3 along the cotectic pigeonite-diopside-forsterite-liquid (Longhi \& Boudreau, 1980).

The last reaction is the martensitic transformation (Shimobayashi \& Kitamura, 1991) of high pigeonite $(C 2 / c$, in the unmelted cpx-3 augite + high pigeonite $)$ into low pigeonite $\left(P 2_{1} / c\right)$ : cpx-5. The temperature of this phase transition depends on pigeonite composition, from $1000^{\circ} \mathrm{C}$ for $\mathrm{Mg}$-rich ones to $500^{\circ} \mathrm{C}$ for $\mathrm{Fe}$ rich ones (Prewitt et al., 1971; Fuess et al., 1986).

We assume that the laihunite was formed by the oxidation of olivine between 800 and $400^{\circ} \mathrm{C}$ (Kondoh et al., 1985).

\section{Discussion}

\section{Chronology of the reaction (Fig. 7)}

The first visible reaction in the xenolith is the topotactic transformation of opx-1 into cpx-2 due to the incorporation of the xenolith in the basalt. The sub-

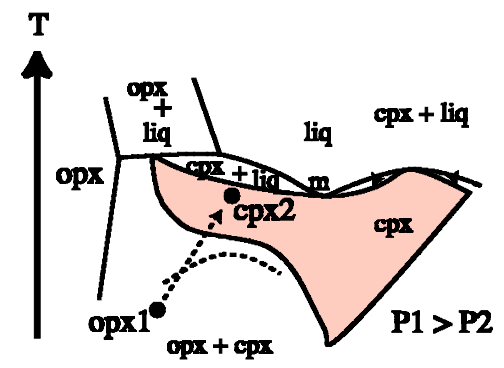

a) Incorporation of the xenolith in the host magma.

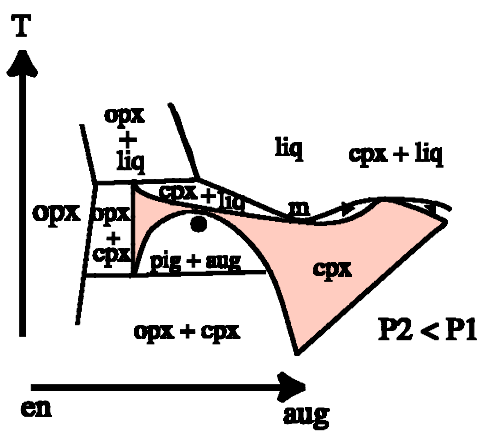

b) Decreasing pressure due to xenolith ascent to the surface.

Fig. 7. Two isobaric temperature- composition schematic diagrams relevant to the reactions observed in opx-1, after Longhi \& Bertka (1996). Solid circles represent the composition of the minerals studied. However, the phase diagrams are not well constrained for this composition. a) Reaction 1 : opx-1 $\Rightarrow$ cpx-2 corresponds to the incorporation of the xenolith in the host magma ( $\mathrm{T}$ increases). The calcium in cpx2 probably originates from the host basalt or from plagioclase melting. b) Upon decreasing pressure due to xenolith ascent to the surface, cpx-2 decomposes and undergoes phase separation to augite $(C 2 / c)$ and high pigeonite $(C 2 / c)$.

sequent step is the drop of pressure due to ascent of the lava. At this stage, cpx-2 undergoes a phase separation into augite $(C 2 / c)$ and high pigeonite $(C 2 /$ $c$ ). This phase assemblage constitutes cpx-3. As xenolith ascent proceeds, cpx-3 melts, in response to new pressure conditions, then it partially crystallises as cpx-4 and Fe-Ti oxides. Then cooling of the non-melted cpx-3 produces spinodal decomposition and martensitic transformation from $C 2 / c$ high pigeonite to $P 2_{1} / c$ low pigeonite.

Recent work on pyroxene phase equilibria established from experimental data and topological constraints (Bertka \& Holloway, 1993; Longhi \& Bertka, 1996) allows us to locate the reactions in 
the pressure and temperature fields. However, the phase diagrams are not well constrained for our natural pyroxenes. The incorporation of the xenolith into the magma corresponds to an isobaric temperature increase leading to reaction 1 : opx-1 $\Rightarrow$ cpx-2. The xenolith ascent corresponds to a nearly isothermal decompression that may explain reaction 2: cpx-2 $\Rightarrow$ pigeonite + augite. The next reaction (3) (pigeonite + augite $\Rightarrow$ liquid) is due to the pressure decrease as well, but here melting occurs eutectically (composition m, Fig. 7).

\section{Estimate of the xenolith ascent velocity}

The aim of this part is to assess the time required for development of the various textures. A similar method using amphibole breakdown has been applied to estimate magma ascent rates for the Mount $S^{t}$ Helens eruptions (Rutherford \& Hill, 1993).

\section{1/ Ascent-time estimate}

Ascent time is given by the time between the incorporation into the magma (reaction 1: opx-1 $\Rightarrow \mathrm{cpx}-2$ ) and the eruption (final crystallisation at low pressure).

\section{a) Reaction 1 (opx-1 $\Rightarrow$ cpx-2)}

This reaction corresponds to the heating of the xenolith in the basalt. Selverstone (1982) showed that the complete heating $\left(1200^{\circ} \mathrm{C}\right)$ of a $10 \mathrm{~cm}$-xenolith requires 2-3 hours. The diameter of the xenolith we have studied is much smaller (on the order of $4 \mathrm{~cm}$ ), therefore the xenolith reached the host-basalt temperature more rapidly. The time necessary for this stage has been estimated at about 18 minutes though the simplified equation $t=x^{2} / x$, where $\mathrm{x}$ is the distance between the centre of orthopyroxene and host basalt (about $5 \mathrm{~mm}$ ), and $\boldsymbol{x}$ the thermal conductivity. However, the time was probably shorter because heat was also transferred to the xenolith by infiltration of the host magma into it.

\section{b) Reaction 2 (cpx-2 $\Rightarrow$ [augite $C 2 / c+$ high pigeon- ite $C 2 / c]$ )}

The time required for the exsolution lamellae to develop can be calculated using the calcium diffusion rate. Figure $5 \mathrm{~b}$ shows that the width of exsolution lamellae is about $50 \mathrm{~nm}$. Although the calcium diffusion coefficient in pyroxene is not well know (Freer et al., 1982), the minimum time required to develop these exsolution lamellae was calculated using a calcium diffusion coefficient of $\mathrm{D} \approx 10^{-}$
${ }^{15} \mathrm{~cm}^{2} \cdot \mathrm{s}^{-1}$ (Freer et al., 1982) and the simplified equation given by Crank (1975): $t \approx h^{2} / D$, where $h$ is the distance $(\mathrm{cm})$ between the centres of adjacent lamellae, each lamella being bisected by a plane of symmetry (Brady \& McCallister, 1983), and tis the time in seconds. We find a minimum of 7 hours.

\section{c) Reaction 3 (melting of the pyroxene)}

Here the time is estimated through the size of the melt film which varies from $500 \mathrm{~nm}$ to $2 \mu \mathrm{m}$. According to Tsuchiyama (1986), the width of melt pools $(\Delta x)$ is roughly proportional to the square root of time $\left(\mathrm{t}^{1 / 2}\right), \Delta \mathrm{x}=\mathrm{k} \mathrm{t}^{1 / 2}$, where $\mathrm{k}$ approximately satisfies an Arrhenius law. For temperatures of about $1250^{\circ} \mathrm{C}$ and pressure of $5 \mathrm{kbar}, \mathrm{k}=1.11 \times 10^{-6}$ $\mathrm{cm} . \mathrm{s}^{-1}$ (Brearley \& Scarfe, 1986), so 30 minutes to 9 hours are necessary.

Therefore the cumulated time needed for these reactions to occur suggests a minimum xenolith ascent time of about16 hours.

\section{2/ Depth estimate}

Only the maximum pressure of the xenolith is known: 0.7-0.8 GPa. Goër de Herve et al. (1991) proposed that this volcano has a magma chamber located at the bottom of the lower crust, because it contains abundant peridotitic nodules and because the magma is non differentiated. At present, a total crustal thickness of about 27 to $30 \mathrm{~km}$ is inferred in this area from seismic studies (Perrier \& Ruegg, 1973; Hirn, 1976; Souriau et al., 1981; Sobolev et al., 1996). Therefore, we propose that the initial depth of this xenolith was $30 \mathrm{~km}$.

\section{3/ Ascent-velocity estimate}

If we accept that the granulite xenolith has been scavenged from the bottom of the lower crust $(30 \mathrm{~km})$ and reached the surface in $16 \mathrm{~h}$, then its ascent velocity may be estimated to be about $1.8 \mathrm{~km} \cdot \mathrm{h}^{-1}$ (Fig. 8). This is in good agreement with other results reported in the literature. From Stokes' law applied to xenoliths, Spera (1980) estimated ascent velocities of basalts to be in the range $0.36-36 \mathrm{~km} \cdot \mathrm{h}^{-1}$. Morin \& Corriveau (1996) proposed a minimum ascent velocity of 1.8 $\mathrm{km} . \mathrm{h}^{-1}$ using the same method. Scandone \& Malone (1985) estimated magma ascent times of about 2.1$2.5 \mathrm{~km} \cdot \mathrm{h}^{-1}$ on the basis of seismic evidence at Mount $\mathrm{S}^{\mathrm{t}}$ Helens. A minimum Stokes ascent velocity in the range $0.36-1.44 \mathrm{~km} \cdot \mathrm{h}^{-1}$ has been estimated from the largest xenoliths $\left(1.689 \mathrm{~kg}, 489.6 \mathrm{~cm}^{3}\right)$ in Beaunit (written comm., Aurejac, 1997). 

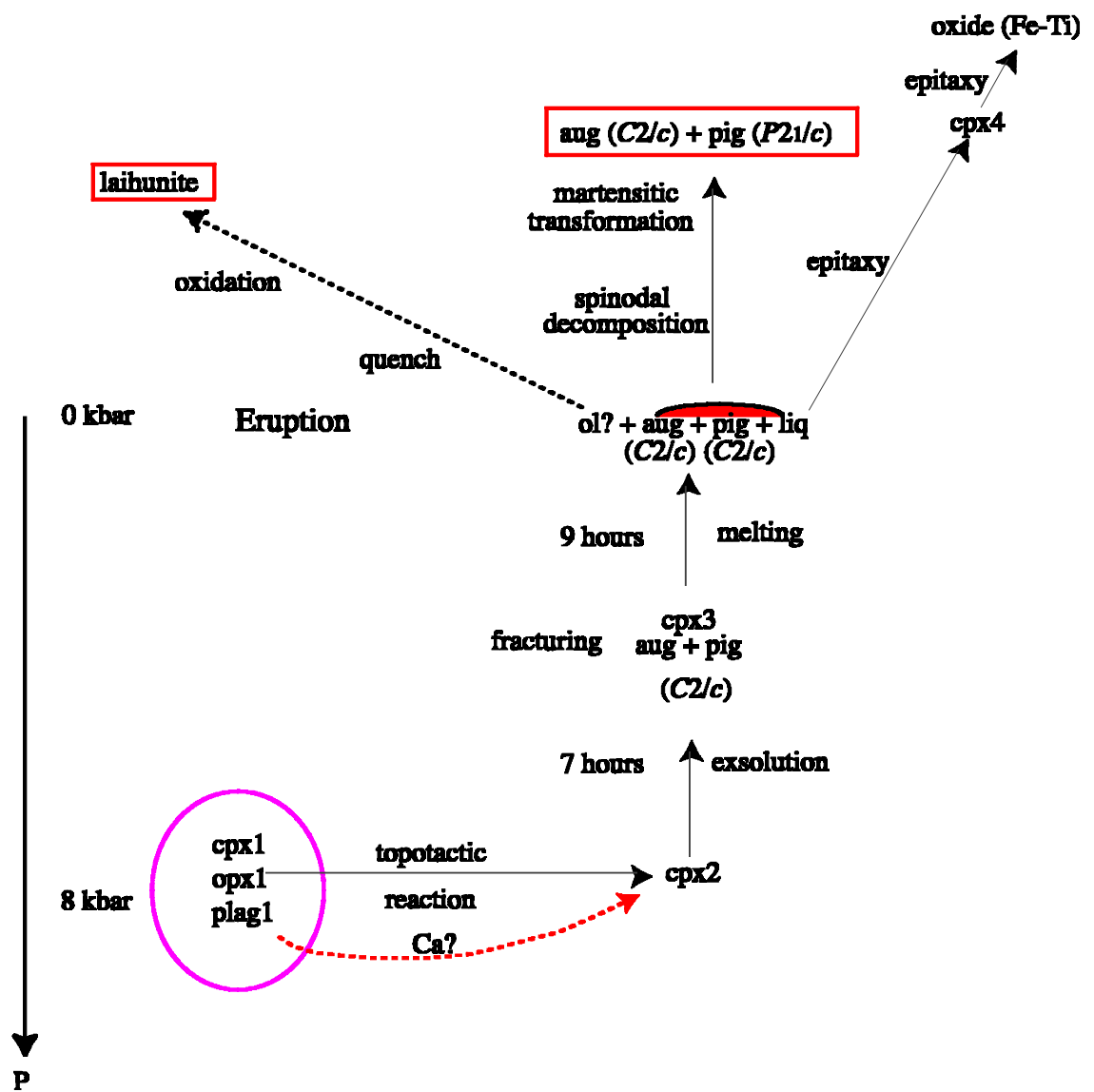

Fig. 8. Diagram indicating the path followed by the xenolith from extraction to final eruption with the host basalt. The series of reactions observed around opx-1 is summarised.

For the particular xenolith studied, the minimum Stokes ascent velocity would be $3 \times 10^{-4}$ $\mathrm{km} \cdot \mathrm{h}^{-1}$, with $2600 \mathrm{~kg} \cdot \mathrm{m}^{-3}$ for the specific gravity of basalt and 16.1 Pa.s for its viscosity (Shaw, 1972). This velocity can be neglected compared to the ascent velocity we found.

\section{The fracturing issue}

Intense fracturing in primary minerals is frequently described from xenoliths (Rudnick, 1992), and can be interpreted in three ways:

- thermal fracturing due to rapid cooling from extrusion temperature to ambient temperature (Dixon et al., 1986) or resulting from incorporation of "cold" xenolith in the "hot" host magma (Bouloton \& Gasquet, 1995),
- decompression due to rapid ascent of the xenolith (Jones et al., 1983; Garvey \& Robinson, 1984), - impact fracturing due to collision amongst xenoliths or collision of the xenolith on the walls of the conduit (Dixon et al., 1986; Morin \& Corriveau, 1996).

The textural observations we made exclude thermal fracturing during the incorporation of the xenolith in the magma, since this mechanism should affect only opx-1 (Fig. 2). Both opx-1 and $\mathrm{cpx}-2$ are affected by the same fractures, and since cpx-2 resulted from the transformation of opx-1 during heating above $1200^{\circ} \mathrm{C}$, it means that fracturing occurred after this stage. Moreover, opx-1 fracturing prior to cpx-2 formation would have let the basaltic magma penetrate along the fractures leading to a preferential cpx-2 formation along these fractures, a feature which is not observed (Fig. 2a). 
Thermal fracturing due to rapid cooling is also not a suitable mechanism because some minerals, which are formed at a late, high-temperature stage (cpx-4, olivine and oxide), are not fractured. Therefore, fracturing should have occurred in the xenolith when it was transported by the basalt, and collision is the best hypothesis for explaining it. However, collision should have occurred before the crystals melted and became ductile. It is worth noting that some recent investigations of pyroxene rheology showed that this mineral becomes harder as temperature increases (Raterron \& Jaoul, 1991; Ingrin et al., 1991) because of the development of early partial melting.

If we assume that fracturation occurred by collision, we must imagine that the magma had a vigorous turbulent behaviour (Reynolds number $\mathrm{Re}>$ 1000). This is achieved only if the minimum width of the magmatic conduit were about $20 \mathrm{~m}$. According to Morin \& Corriveau (1996) this is unlikely in the lower crust, and these authors suggested that impacts between xenoliths are produced by local constriction and plugging of the conduit.

\section{Conclusion}

Several steps of the history of a single xenolith have been deciphered. This includes: the initial heating during the incorporation in the basalt, the decompression during the ascent, and the rapid cooling during the eruption. Each of this stage is marked by various reactions that must be studied carefully in order to reconstruct the chronology of the transformation, using crosscutting relationships and epitaxy relationships. The various relationships between clinopyroxene and orthopyroxene proved to be very rich in information, because those transformations are very sensitive to kinetics factors. Of particular interest is the formation of exsolution lamellae by pressure decrease, instead of temperature decrease as usually interpreted in similar contexts.

This study shows that detailed petrographical studies involving modern methods of observation may severely constrain parameters as important as the timescale of magma transport or the nature of the fluid regime during basalt ascent.

Acknowledgements: We thank J.-B. Aurejac for providing xenoliths data on the Beaunit Maar. We have benefited from discussions with many colleagues, including D. Laporte, P. Boivin, A. Baron- net and B. Devouard. The authors wish to thank M. Mazzucchelli and F. Cámara for their useful reviews. We are grateful to B. Soulestin for careful preparation of TEM specimens and M. Veschambre for assistance with the electron microprobe work.

\section{References}

Bailey, J.C., Champness, P.E., Dunham, A.C., Esson, J., Fyfe, W.S., MacKenzie, W.S., Stumpfl, E.P., Zussman, J. (1970): Mineralogy and petrology of Apollo 11 lunar samples. Proc. Apollo 11 Lunar Sci. Conf., 169-194.

Banfield, J.F., Veblen, D.R., Jones, B.F. (1990): Transmission electron microscopy of subsolidus oxidation and weathering of olivine. Contrib. Mineral. Petrol., 106, $110-123$.

Berger, E. \& Forette, M.-C. (1975): Réactions de basaltes alcalins des Causses, du Vivarais et du Velay (France) avec les xenocristaux et les minéraux des enclaves homeogènes. Bull. Soc. fr. Minéral. Cristallogr., 98, 366373.

Berman, R.G. (1991): Thermobarometry using multi-equilibrium calculations: a new technique, with petrological applications. Can. Mineral., 29, 833-855.

Bertka, C.M. \& Holloway, J.R. (1993): Pigeonite at solidus temperatures: implications for partial melting. J. Geophys. Res., 98, 19755-19766.

Bouloton, J. \& Gasquet, D. (1995): Melting and undercooled crystallisation of felsic xenoliths from minor intrusions (Jebilet massif, Morocco). Lithos, 35, 201219.

Brady, J.B. \& McCallister, R.H. (1983): Diffusion data for clinopyroxenes from homogenization and self-diffusion experiments. Am. Mineral., 68, 95-105.

Brearley, M. \& Scarfe, C.M. (1986): Dissolution rates of upper mantle minerals in an alkali basalt melt at high pressure: an experimental study and implications for ultramafic xenolith survival. J. Petrol., 27, 1157-1182.

Brousse, R. \& Rudel, A. (1964): Bombes de péridotites, de norites, de charnockites et de granulites dans les scories du Puy Beaunit. C.R. Acad. Sc. Paris, 259, 185-189.

Camus, G. (1975): La Chaîne des Puys (Massif Central Français). Etude structurale et volcanologique. Thèse Université de Clermont-Ferrand, Annales Scientifiques de l'Université de Clermont, 322 p.

Champness, P.E. \& Lorimer, G.W. (1976): Exsolution in silicates. In "Electron microscopy in mineralogy", H. R. Wenk, ed. Springer-Verlag, New York, 174-204.

Chen, W. \& Arculus, R.J. (1995): Geochemical and isotopic characteristics of lower crustal xenoliths, San Francisco Volcanic Field, Arizona, USA. Lithos, 36, 203-225.

Copley, P.A., Champness, P.E., Lorimer, G.W. (1974): Electron petrography of exsolution textures in an ironrich clinopyroxene. J. Petrol., 15, 41-57.

Crank, J. (1975): The mathematics of diffusion. Clarendon press, Oxford science publications, $414 \mathrm{p}$. 
Dixon, J.E., Glague, D.A., Eissen, J.-P. (1986): Gabbroic xenoliths and host ferrobasalt from the Southern Juan de Fuca Ridge. J. Geophys. Res., 91, 3795-3820.

Donaldson, C.H. (1976): An experimental investigation of olivine morphology. Contrib. Mineral. Petrol., 57, 187213.

- (1977) Laboratory duplication of comb layering in the Rhum pluton. Mineral. Mag., 41, 323-336.

Dostal, J., Dupuy, C., Leyreloup, A. (1980): Geochemistry and petrology of meta-igneous granulitic xenoliths in Neogene volcanic rocks of the Massif Central, FranceImplications for the lower crust. Earth Planet. Sci. Lett., 50, 31-40.

Downes, H., Dupuy, C., Leyreloup, A. (1990): Crustal evolution of the Hercynian belt of western Europe: evidence from lower crustal xenoliths (French MassifCentral). Chemical Geol., 83, 209-231.

Feuer, H., Schröpfer, L., Fuess, H., Jefferson, D.A. (1989): High resolution transmission electron microscope study of exsolution in synthetic pigeonite. Eur. J. Mineral., 1, 507-516.

Freer, R., Carpenter, M.A., Long, J.V.P., Reed, S.J.B. (1982): "Null result" diffusion experiments with diopside: implications for pyroxene equilibria. Earth Planet. Sci. Lett., 58, 285-292.

Fuess, H., Schröpfer, L., Feuer, H. (1986): Exsolution and phase transformations in synthetic pyroxenes: X-ray and TEM-studies at elevated temperatures. Ber. Bunsenges. Phys. Chem., 90, 755-759.

Garvey, O.C. \& Robinson, D.N. (1984): The formation of kelyphite and associated subkelyphite sculptured surfaces on pyrope from kimberlite. In "Kimberlites and Related Rocks", J. Kornprobst, ed. Elsevier, 371-382.

Goër de Herve (de), A., Boivin, P., Camus, G., Gourgaud, A., Kieffer, G., Mergoil, J., Vincent, P. (1991): Volcanologie de la chaîne des Puys, Parc Naturel Régional des Volcans d'Auvergne. Imp. moderne ed., Aurillac, 127 p.

Graham, I.J., Grapes, R.H., Kifle, K. (1988): Buchitic metagreywacke xenoliths from mount NGauruhoe, Taupo Volcanic zone, New Zealand. J. Volcanol. Geotherm. Res., 35, 205-216.

Grapes, R.H. (1986): Melting and thermal reconstitution of pelitic xenoliths, Wehr Volcano, East Eifel, West Germany. J. Petrol., 27, 343-396.

Green, D.H. \& Ringwood, A. E. (1967): An experimental investigation of the gabbro to eclogite transformation and its petrological applications. Geochim. Cosmochim. Acta, 31, 767-833.

Green, T.H. (1967): An experimental investigation of sub solidus assemblages formed at high pressure in high alumina basalt, kyanite eclogite and grosspydite compositions. Contrib. Mineral. Petrol., 16, 84-114.

Harris, C. \& Bell, J.D. (1982): Natural partial melting of syenite blocks from Ascension Island. Contrib. Mineral. Petrol., 79, 107-113.

Hirn, A. (1976): Sondages sismiques profonds en France. Bull. Soc. géol. Fr., 5, 1065-1071.

Hovmöller, S. (1992): CRISP: crystallographic image pro- cessing on a personal computer. Ultramicroscopy, 41, 121-135.

Ingrin, J., Doukhan, N., Doukhan, J.C. (1991): High-temperature deformation of diopside single crystal 2 . Transmission electron microscopy investigation of the defect microstructures J. Geophys. Res., 96, 1428714297.

Jones, A.P., Smith, J.V., Dawson, J.B., Hansen, E.C. (1983): Metamorphism, partial melting, and K-metasomatism of garnet-scapolite-kyanite granulite xenoliths from Lashisne, Tanzanie. J. Geology, 91, 143-166.

Jurewicz, A. J.G. \& Watson, B.E. (1988): Cations in olivine, Part 1: Calcium partitioning and calcium-magnesium distribution between olivines and coexisting melts, with petrologic applications. Contrib. Mineral. Petrol., 99, 176-185.

Kohlstedt, D.L. \& Vander Sande, J.B. (1976): On the detailed structure of ledges in augite-enstatiteinterface. In "Electron Microscopy in Mineralogy", H.R. Wenk, ed. Springer-Verlag, New-York, 234-237.

Kondoh, S., Kitamura, M., Morimoto, N. (1985): Synthetic laihunite $\left(\square_{\mathrm{x}} \mathrm{Fe}_{2.3 \mathrm{x}}^{2+} \mathrm{SiO}_{4}\right)$, an oxidation product of olivine. Am. Mineral., 70, 737-746.

Laporte, D. \& Watson, E.B. (1995): Experimental and theoretical constraints on melt distribution in crustal sources: the effect of crystalline anisotropy on melt interconnectivity. Chemical Geol., 124, 161-184.

Lee, D.- C., Halliday, A.N., Hunter, R.H., Holden, P., Upton, B.G.J. (1993): Rb-Sr and Sm-Nd isotopic variations in dissected crustal xenoliths. Geochim. Cosmochim. Acta, 57, 219-230.

Leyreloup, A. (1973): Le socle profond en Velay d'après les enclaves remontées par les volcans Néogènes. Son thermométamorphisme et sa lithologie: granite et série charnockitique. (Massif Central Français). Thèse 3 cycle, Nantes, $356 \mathrm{p}$.

Lofgren, G.E. \& Donaldson, C.H. (1975): Curved branching crystals and differentiation in comb-layered rocks. Contrib. Mineral. Petrol., 49, 309-319.

Longhi, J. \& Bertka, C.M. (1996): Graphical analysis of pigeonite-augite liquidus equilibria. Am. Mineral., 81, 685-695.

Longhi, J. \& Boudreau, A.E. (1980): The orthoenstatite liquidus field in the system forsterite-diopside-silica at one atmosphere. Am. Mineral., 65, 563-573.

Maury, R.C. \& Bizouard, H. (1974): Melting of acid xenoliths into a basanite: An approach to the possible mechanisms of crustal contamination. Contrib. Mineral. Petrol., 48, 275-286.

Morin, D. \& Corriveau, L. (1996): Fragmentation processes and xenolith transport in a Proterozoic minette dyke, Grenville Province, Québec. Contrib. Mineral. Petrol., 125, 319-331.

Nord, G.L., jr., Heuer, A.H., Lally, J.S. (1976): Pigeonite exsolution from augite. In "Electron Microscopy in Mineralogy", H.R. Wenk, ed. Springer-Verlag, New York, 234-237.

O’Reilly, S.Y., Nicholls, I.A., Griffin, W.L. (1989): Xeno- 
liths and megacrysts of mantle origin. In "Intraplate volcanism in Easter Australia and New Zealand”, R.W. Johnson, ed. Cambridge Univ. Press, 254-274.

Perrier, G. \& Ruegg, J.C. (1973): Structure profonde du Massif Central français. Ann. Géophys., 29, 435-502.

Prewitt, C.T., Brown, G.E., Papike, J.J. (1971): Apollo 12 clinopyroxenes: high temperature X-ray diffraction studies. Proc. Lunar Sci. Conf., 2, 59-68.

Raterron, P. \& Jaoul, O. (1991): High-temperature deformation of diopside single crystal 1 . Mechanical data. $J$. Geophys. Res., 96, 14277-14286.

Robinson, P. (1980): The composition space of terrestrial pyroxenes - internal and external limits. In "Pyroxenes", C.T. Prewitt, ed. Reviews in Mineralogy, 419475.

Rosseel, J.-B. (1996): Synthèse chrono-magmatologique de la Chaîne des Puys. Unpublished diploma thesis (DEA), Univ. B. Pascal, Clermont-Ferrand II, 50 p.

Rudnick, R.L. (1992): Xenoliths samples of the lower continental crust. In "Developments in geotectonics", D. M. Fountain, R. Arculus, R. W. Kay, eds. Elsevier, Amsterdam-London-New-York-Tokyo, 269-316.

Rutherford, M.J. \& Hill, P.M. (1993): Magma ascent rates from amphibole breakdown: an experimental study applied to the 1980-1986 Mount St.Helens eruptions. $J$. Geophys. Res., 98, 19667-19685.

Scandone, R. \& Malone S.D. (1985): Magma supply, magma discharge and reajustment of the feeding system of Mount S. ${ }^{t}$ Helens during 1980. J. Volcanol. Geotherm. Res., 23, 239-262.

Selverstone, J. (1982): Fluid inclusions as petrogenetic indicators in granulite xenoliths, Pali-Aike Volcanic Field, Chile. Contrib. Mineral. Petrol., 79, 28-36.

Shaw, R.H.(1972). Viscosities of magmatic silicate liquids: an empirical method of prediction. Am. J. Sci., 272, 870-893.

Shimobayashi, N. \& Kitamura, M. (1991): Phase transition in Ca-poor clinopyroxenes. A high temperature transmission electron microscopic study. Phys. Chem. Minerals, 18, 153-160.
- (1993): Phase transition of orthoenstatite to high-clinoenstatite: in situ TEM study at high temperatures. Mineral. J., 16, 416-426.

Sobolev, S. V., Zeyen, H., Stoll, G., Werling, F. (1996): Upper mantle temperatures from teleseismic tomography of French Massif Central including effects of composition, mineral reactions, anharmonicity, anelasticity and partial melt. Earth Planet. Sci. Lett., 139, 147-163.

Souriau, A., Correig, A.M., Souriau, M. (1981): Attenuation of Rayleigh waves across the volcanic area of the Massif Central, France. Phys. Earth Planet. Inter., 23, 62-71.

Spera, F. J. (1980): Aspects of magma transport. In "Physics of magmatic processes", R.B. Hargraves, ed. Princeton Univ. Press, 265-323.

Tamada, O., Shen, B., Morimoto, N. (1983): The crystal structure of laihunite $\left(\square_{0.4} \mathrm{Fe}_{0,8}^{2+} \mathrm{Fe}_{0,8}^{3+} \mathrm{SiO}_{4}\right)$ - nonstoichiometric olivine-type mineral.Mineral. J., 11, 382-391.

Tsuchiyama, A. (1986): Melting and dissolution kinetics: application to partial melting and dissolution of xenoliths. J. Geophys. Res., 91, 9395-9406.

Tsuchiyama, A. \& Takahashi, E. (1983): Melting kinetics of a plagioclase feldspar. Contrib. Mineral. Petrol., 84, 345-354.

Usselman, T.M. , Lofgren, G.E., Donaldson, C.H., Williams, R.J. (1975): Experimentally reproduced textures and mineral chemistries of high-titanium mare basalts. Proc. Lunar Sci. Conf., 6, 997-1020.

Warner, R.D. \& Wasilewski, P.J. (1995): Magnetic petrology of lower crust and upper mantle xenoliths from Mc Murdo Sound, Antarctica. Tectonophysics, 249, 69-92.

Wysoczanski, R.J. , Gamble, J.A., Kyle, P.R., Thirlwall, M.F. (1995): The petrology of lower crustal xenoliths from the Executive Committee Range, Marie Byrd Land Volcanic Province, West Antarctica. Lithos, 36, 185-201.

Received 21 June 1999

Modified version received 14 September 2000

Accepted 18 September 2000 